\title{
Public Archaeologies from the Edge
}

\author{
Pauline Clarke, Kieran Gleave and Howard Williams
}

The chapter serves to introduce the first-ever book dedicated to public archaeologies of frontiers and borderlands. We identify the hitherto neglect of this critical field which seeks to explore the heritage, public engagements, popular cultures and politics of frontiers and borderlands past and present. We review the 2019 conference organised by Uiversity of Chester Archaeology students at the Grosvenor Museum, Chester, which inspired this book, and then survey the structure and contents of the collection. We advocate that public archaeologies should seek to incorporate and foreground perspectives 'from the edge'. By this we mean public archaeology should make frontiers and borderlands - including the people living with them and seeking to traverse them - paramount to future work.

From IndyRef and Brexit, to the Refugee Crisis and Trump's Wall, frontiers dominate our news. In exploring both past and contemporary frontiers and borderlands, archaeological research can provide innovative perspectives and insights, revealing their creation, use, translation, removal, subversion, circumvention and reinvention. Sustained archaeological investigations can identify how frontier monuments and landscapes are not merely lines on a map, but zones that might possess topographic, economic, social, political, religious and ideological dimensions and may acquire biographies and significances contrasting from those intended and long after their creation (e.g. Hingley 2012). Borderlands, meanwhile, need not relate to clearly defined zones either side of a coherent 'border', but creative and fluid 'third spaces' distinct from core territories of polities; they can be networks where communities and social relations are transformed and re-fashioned (e.g. Naum 2010). Frontiers and borderlands can thus operate as zones of interaction and creativity as much as barriers and blockades. In these environments, new identities and societies can be fostered and reproduced.

Yet, while archaeologists have participated in exploring borderlands in the distant and recent past, including linear boundaries and their long life-histories (for a review survey, see Williams and Delaney 2019), the public archaeology of frontiers and borderlands has received no sustained attention. Given the aspiration to regard public archaeology as a multi-strand subdiscipline which explores and critiques archaeology's intersections with contemporary society (e.g. Moshenska 2017), and set against the rise of critical investigations of contemporary dispossessed and displaced peoples (e.g. Hamilakis 2018), this is nothing short of a collective dereliction of duty among those working in public archaeology. This neglect is especially striking when so many community projects, heritage sites, museums and public-facing print and digital media involve archaeological narratives with a direct bearing on this theme. We contend they have a fundamental responsibility to shift away from narratives focused on 'peoples' and communities within bound transhistorical geographical boundaries. Instead, we propose that archaeologists should produce sustained critiques of over-simplified and politicised visions of past peoples and their landscapes. Starting on the 'edge': with their boundaries and frontiers, and with marginalised peoples living with and crossing borders, should be a priority for future research in public archaeology. Two striking exceptions to this situation are known to us in Britain, and both relate to the frontier works of the Roman Empire: the heritage interpretation of Hadrian's Wall (Witcher 2010a and b; Hingley 2012: 275-336; Hingley 2018) and the digital investigation of the use of the Iron Age and Roman past in contemporary political discourses surrounding Brexit (Bonacchi et al. 2018; see also Gardner 2017; Brophy 2018). Yet, there have been very few sustained community projects which have tackled frontiers and borderlands, including their linear monuments, effectively (O' Drisceoil et al. 2014; Williams and Evans 2020; see also Collins this volume), and these often struggle to tell the stories of those seeking to cross them (Stewart et al. 2018; Hicks and Mallet 2019). Even public archaeology projects focused on coastlines and islands fixate on their landward associations 
rather than interconnections. Whether participating in projects relating to parishes, counties, national borderlands, natural thresholds and frontiers (such as mountain ranges, coastlines, wetlands and rivers), almost all public archaeology finds itself speaking of place and territories, and thus practitioners are forced to navigate modern mythologies and histories about them, mediated via material culture. These often focus on anxieties and fascinations, horrors and fantasies, regarding boundaries and boundedness, walls and borders as they emerge and shift (see also Witcher 2010b).

Therefore, the broader task of public archaeologies of frontiers and borderlands is an as-yet largely unexplored field. Operating alongside the burgeoning study of undocumented migration from archaeological perspectives (see Hamilakis 2018), we might profitably seek to engage publics with the archaeological heritage of borderland communities but also frontier stories told in other (physical and digital) places and spaces too, in educating and critiquing popular (mis)understandings of walls and other linear monuments and infrastructures. In some instances, this might take the form of direct action and critique of political discourses, policies and practices, as strikingly revealed for archaeological work across the US/México border (Stewart et al. 2018). In other circumstances, it might take us into rethinking how museums and heritage sites narrate
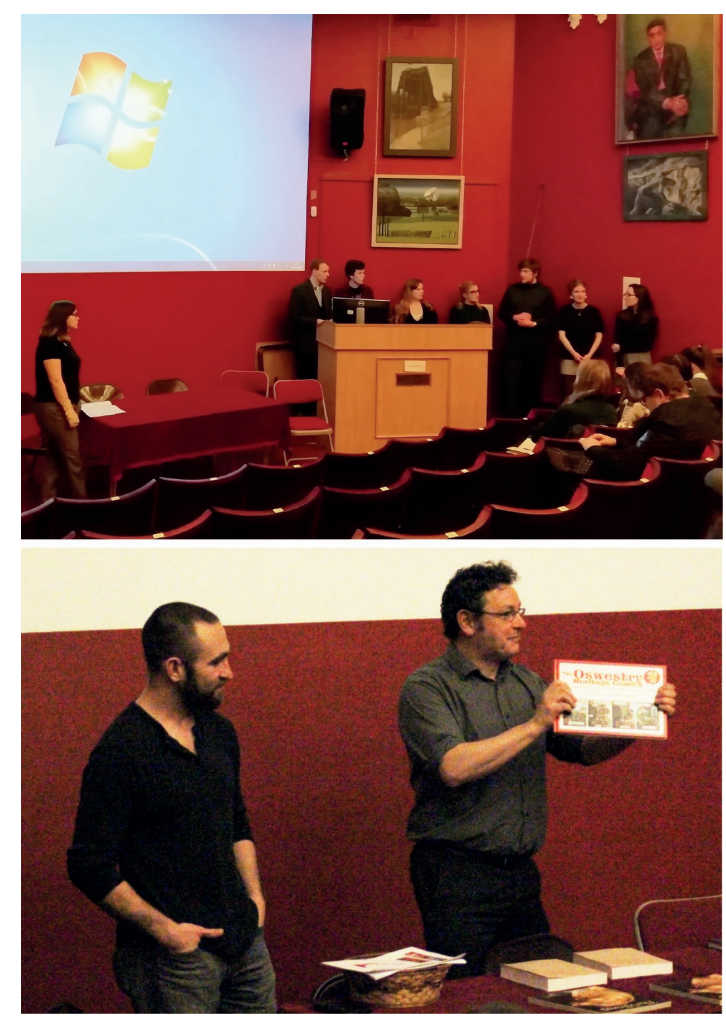

Figure 1: The 4th University of Chester Archaeology Student Conference: the students in discussion after their final session (above) and Dr Brian Costello and Professor Howard Williams raffle books and journal as prizes including John G. Swogger's Oswestry Heritage Comics at the end (below)! (Photographs: Howard Williams, 2019) the past in ways that escape and critique colonial discourses and reject the legitimisation of modern nations and their ethno-nationalist origin myths (e.g. Polm 2016). Whether frontiers and borderlands are the primary focus or not, thinking and practices from the 'edge', from peripheries, allows us fresh, post-colonial and counter-nationalist perspectives on familiar and seemingly comfortable narratives on the past. Public archaeologies from the edge not only 'centre' the dispossessed and dislocated, but foreground the potential and actual violence of frontiers during and after their construction and use (see also Hicks and Mallet 2019). Public archaeologies of frontiers also takes us into digital environments as media for communication and education, as tools for investigation of popular perceptions of walls and borders. They also encourage us to explores virtual and fictional environments where popular ideas regarding frontiers and borderlands are created, afforded a sense of pastness and serve in strategies of present-day exclusion and inclusion. Drawing together these perspectives, we contend that it is both a necessity, and a duty, for public archaeologists to tackle frontiers and borderlands in a serious and sustained fashion in future research and archaeological practice. Both in the UK and globally, we should adopt public archaeological research from the 'edge'.

\section{The Public Archaeology of Frontiers and Borderlands conference}

To begin a process of addressing this research lacuna, the 4th University of Chester Archaeology Student Conference tackled the theme of 'The Public Archaeology of Frontiers and Borderlands' on 20 March 2019 

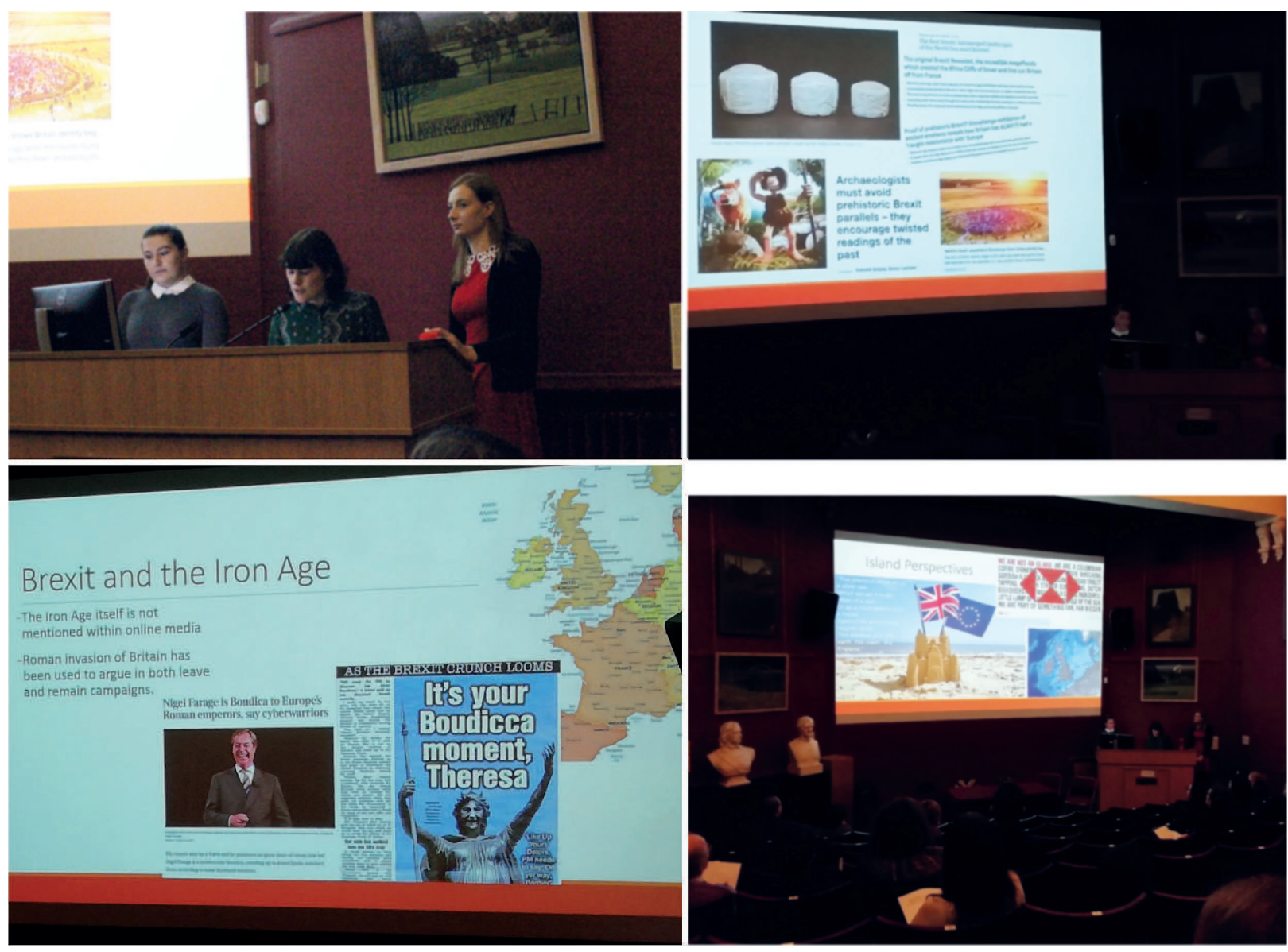

Figure 2: 'Blurred Boundaries: Shifting our Focus from the Land to the Sea', presented by Eleanor Culverhouse, Kelly Griffiths and Rowena Young (Photographs: Kieran Gleave and Howard Williams, 2019)

(Figure 1). The first, second and third student conferences set the precedent for this event, tackling key themes for today's public archaeology in terms of mortuary practice, art/archaeology interactions, and the Early Middle Ages. The format and rationale for those conferences are outlined in their respective proceedings (Williams 2019a and b; Williams et al. 2019; Williams et al. 2020). Specifically, each event has operated simultaneously as research workshops, public outreach events, and as innovative pedagogical exercises for final-year single honours Archaeology students were tasked to organise, participate and reflect on an academic day conference. The final-year students undertook the organisation of the conference and their presentations constituted formative tasks as part of their coursework. Each event was free and open to academics and members of the public alike, rendering them highly distinctive fora in debating new directions in public archaeology.

Given the theme of frontiers and borderlands, it was apposite that the conference was generously hosted, as were the earlier conferences, by the Grosvenor Museum. This is because the lecture theatre of the museum is situated in the heart of the border city of Chester - officially within the English county of Cheshire but with suburbs in modern Wales - and close to the great Mercian frontier works of Offa's Dyke and Wat's Dyke (Ray and Bapty 2016). Indeed, this theme appropriately coincides with the development of the Offa's Dyke Collaboratory (co-founded and co-convened by one of us: Williams) as a research network facilitating and supporting interdisciplinary investigations of frontiers and borderlands past and present, with a focus on the Welsh Marches and its linear earthworks (Williams and Delaney 2019). This has led to the creation of the new open-access academic publication, the Offa's Dyke Journal, which 
provides a unique venue for new research, not only for Offa's Dyke and Wat's Dyke, but also comparative frontiers and borderlands including their monuments and material cultures. Thus, it is only fitting that the book features multiple studies relevant to the Anglo-Welsh borderlands as well as investigations from farther afield.

The resulting conference explored the public archaeology of a diverse range of frontiers and borderlands from a host of geographical locations and time periods. Famous examples from Britain included Hadrian's Wall and offa's Dyke, while those internationally ranged from the Great Wall of China to the Berlin Wall. The final-year Archaeology students had a direct

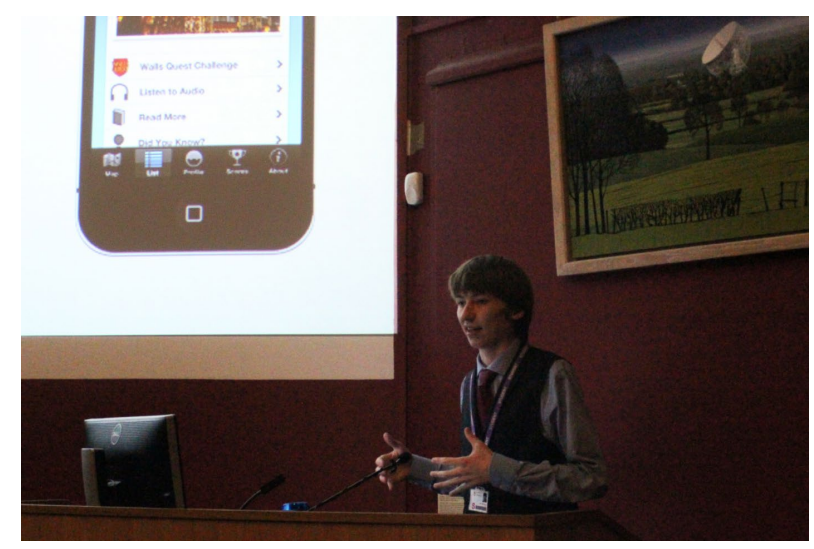

Figure 3: Noah Young presenting 'Academic Discourse and Roman Frontiers: The Interpretation of Deva, the Roman Fortress at Chester, for Younger Audiences and the Wider Public' (Photograph: Howard Williams, 2019) input into how the conference was publicised and ran, from designing the logo and social media platforms (Facebook and Twitter) to chairing the actual sessions themselves and providing refreshments. The conference attracted an audience of c. 50 people, but it was also filmed, edited and uploaded to the University of Chester's Vimeo page where the sessions are free to watch. ${ }^{1}$

The conference adapted the format of previous University of Chester Archaeology Student conferences, with 19 students delivering their talks across three themed sessions which broadly addressed and discussed themes surrounding (i) prehistoric and ancient frontiers; (ii) medieval and global borderlands; and (iii) frontiers in fiction and modernity. Each session was sub-divided into smaller 15-minute student presentations each collating a range of case studies and examples of public archaeology research. Unlike earlier conferences, however, students this time were permitted to deliver joint presentations on a common subject. These varied topic choices allowed the conference to cover a good variety of concepts related to frontiers and borderlands, and opened up a broad range of discussions and debates surrounding public engagement and interaction with archaeological dialogues; discussions surrounding media, heritage management, politics and identity. Three guest presentations and a lively debate enirched the conference.

\section{Prehistoric and ancient frontiers}

The first session of the conference was sub-divided into two student presentations, which focused primarily on how the public engage with concepts and discussions surrounding prehistoric and ancient frontiers, how the themes arising from this may be misused in the wider media. The students tackled what archaeologists can do to combat public misconceptions that arise as a consequence.

'Blurred Boundaries: Shifting our Focus from the Land to the Sea', presented by Eleanor Culverhouse, Kelly Griffiths and Rowena Young, argued that the media misappropriates prehistoric archaeological evidence for the purposes of manipulating contemporary debates surrounding Brexit and in British politics more generally (Figure 2). Young began the presentation with her discussion of how the submersion of Doggerland has been unhelpfully used as a comparison to Brexit. She proceeded by proposing a need from archaeologists to combat such comparisons in the interest of preventing public misinformation. Griffiths identified the issues that can arise from shoehorning Neolithic archaeological

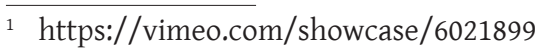



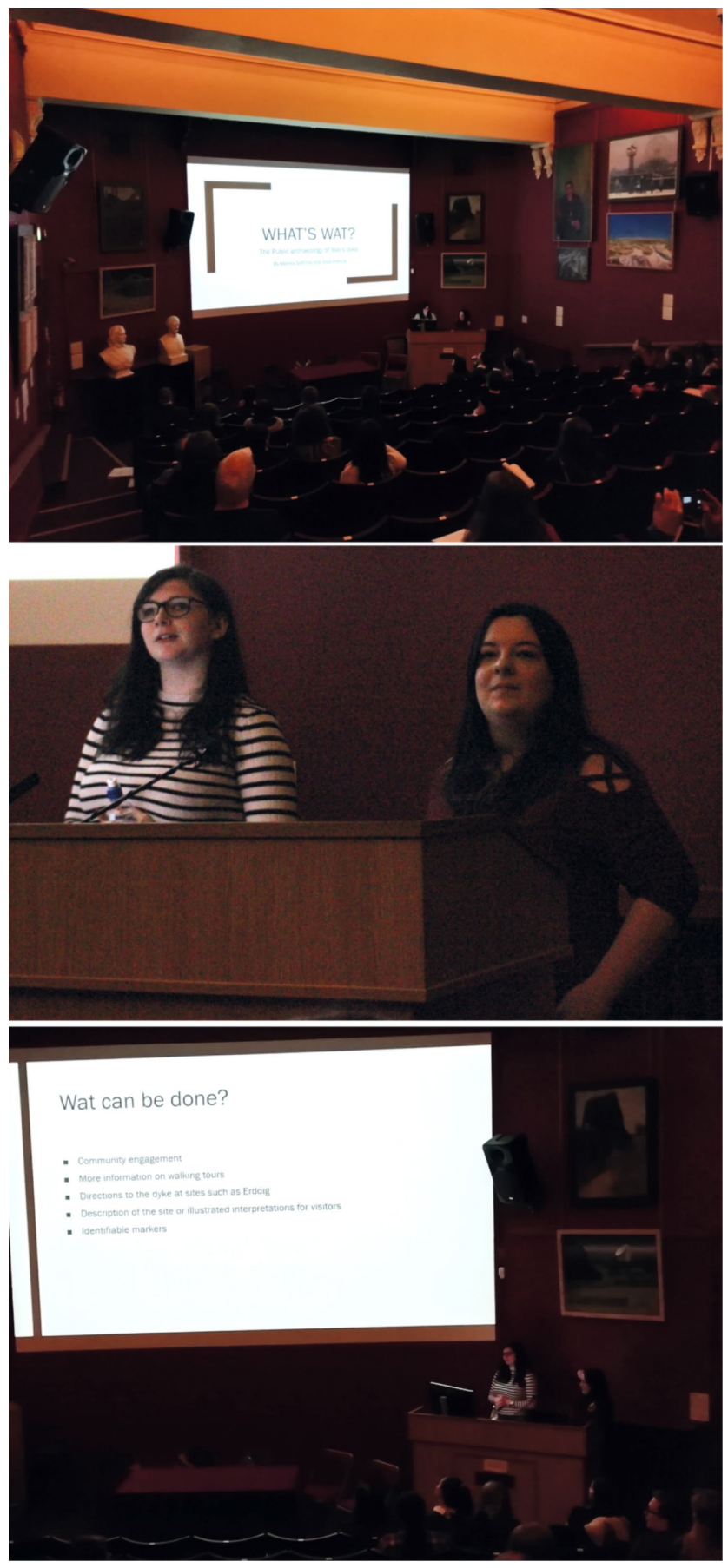

Figure 4: Josie Francis and Mena Griffiths presenting 'What's Wat? The Public Archaeology of Wat's Dyke' (Photograph: Howard Williams, 2019) evidence that appears to be unique to Britain to form notions of modern 'British' identity (see also now Barclay and Brophy 2020). Culverhouse identified how Britain has always been perceived as discrete from the Continent in archaeological discourse, pointing out the close correlations between Iron Age settlement forms shared between Britain and large swathes of north-west Europe. Together, they argued that Brexit, as a modern problem, cannot be equated with any past period and its natural or socio-political borders. Archaeologists have a dual responsibility to ensure that past and present are not equated and to critique and counter political misuses of the present. Both aims are achieved by providing richer and detailed narratives which will enhance the public's understanding of frontiers past.

The second presentation, 'Academic Discourse and Roman Frontiers: The Interpretation of Deva, the RomanFortress at Chester, for Younger Audiences and the Wider Public' by Noah Young considered how to challenge commonly held but incorrect views about Chester's Roman city walls (Figure 3). He identified the importance of making interpretation fun and accessible to younger audiences, using the Chester Portico project as a case study. He argued that one way of combating misinformation about Chester's past is to emphasise Deva's role as part of the Roman frontier and its colonial dimensions. He suggested that Chester, as a fortress, was often unsatisfactorily presented as part of a broader northern British Roman frontier zone with which it was linked by roads and sea with other settlements, forts and Hadrian's Wall (Breeze 2011: 55-70).

\section{Medieval and global borderlands}

The second session of the conference featured three student presentations, each tackling how the public are engaged with key issues surrounding medieval and global borderlands through both heritage interpretation and the past's portrayal in wider forms of media.

'What's Wat? The Public Archaeology of Wat's Dyke' by Josie Francis and Menna Griffiths presented their reflections on the wider public understanding of Wat's Dyke (Malim 2020), identifying a general 
lack of interpretation or clarity for visitors around the location or purpose of the monument (Figure 4). They offered both Welsh and English perspectives on this late 8th/early 9th-century Mercian frontier work and compared its interpretation with its larger and better-known neighbour: Offa's Dyke. They recommended the development of better interpretation panels which could significantly combat the widespread lack of public awareness and understanding surrounding Wat's Dyke (see also Williams this volume).

Josephine Barnes, Rebecca Lloyd and Joe McMullen addressed the complexities that the concept of national and ethnic identities (past and present) can pose to interpreting later medieval borderland castles. Their presentation was titled: 'Identity through Heritage Interpretation in Later Medieval Borderlands Castles' (Figure 5). Lloyd considered the Anglo-Scottish borderland castles, using those at Berwick, Edinburgh and Stirling as case studies, to illustrate the challenge of interpreting historic 'Scottish' and 'English' identity to contemporary audiences; a point especially relevant in the context of the current growth in English nationalism and the Scottish Independence movement. Barnes shifted the discussion to the Welsh March castles of
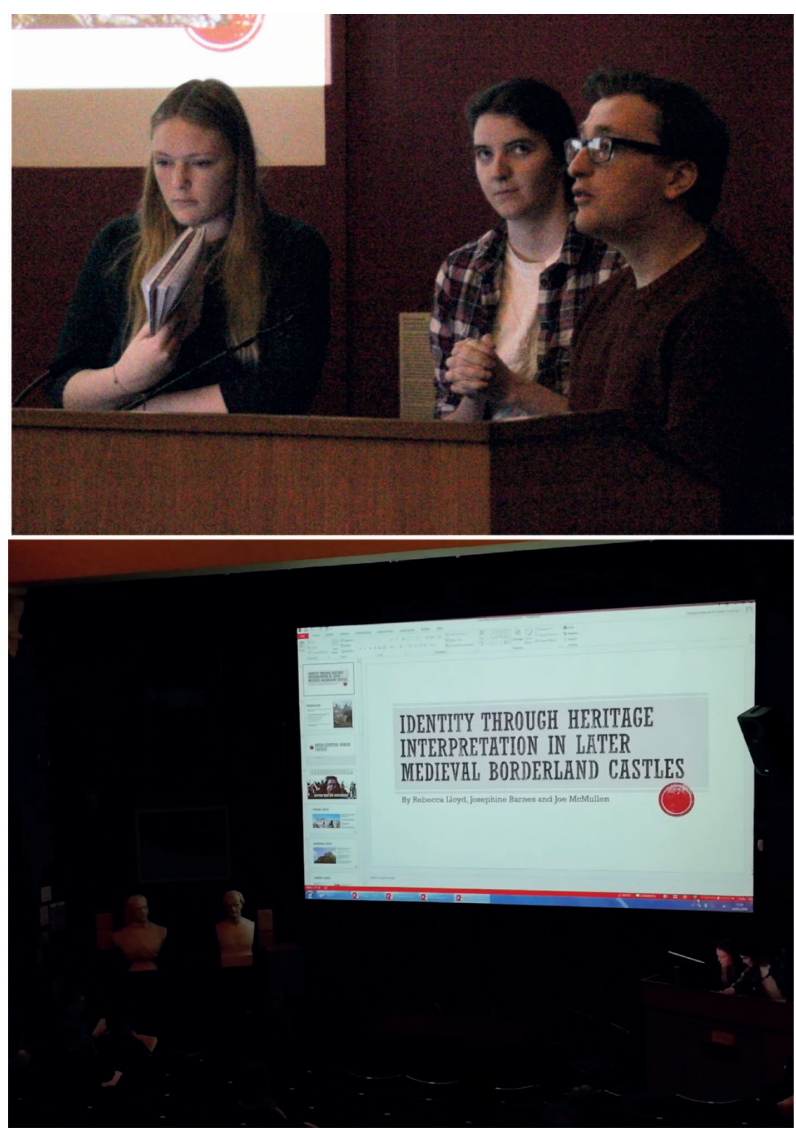

Figure 5: Josephine Barnes, Rebecca Lloyd and Joe McMullen presenting: 'Identity through Heritage Interpretation in Later Medieval Borderlands Castles'

(Photograph: Howard Williams, 2019) Dolforwyn and Flint, in each case identifying how sculpture or traditional sign-based interpretation can pose challenges in the context of contemporary Welsh nationalism and medieval (and modern) English colonialism. Finally, McMullen used Chateu de Falaise, Dover and Porchester castles as case studies to consider the Channel as a frontier in present-day imaginings of the medieval past (see also Nevell and Nevell this volume). In each case, they reflected on the way heritage interpretation relates to contemporary border politics in the light of Brexit and campaigns for Welsh and Scottish independence.

Sophie Billingham and Rebecca Pritchard developed this theme further in reviewing 'The Global Perspective: The Public Archaeology of the Great Wall of China' (Figure 6). They selected two themes concerning how the Wall is portrayed in global, particularly Western, societies. First, Pritchard tackled tourist media: books, guides and websites. She argued that these resources strongly influence the visitor experience and appreciation of the Great Wall to the detriment of understanding its complex history. She argued that the view of the monument as a 'bucket list' destination comes at the expense of an authentic experience, as the well-visited sections are often heavily restored and the broader historical context is left unexplained. Billingham considered the stereotypes (mainly that of the civilised Chinese versus the barbarian Huns) that arise from filmic representations (Billingham this volume). She also considered the wider implications regarding how other ancient walls are portrayed by looking at filmic representations of Hadrian's Wall. 


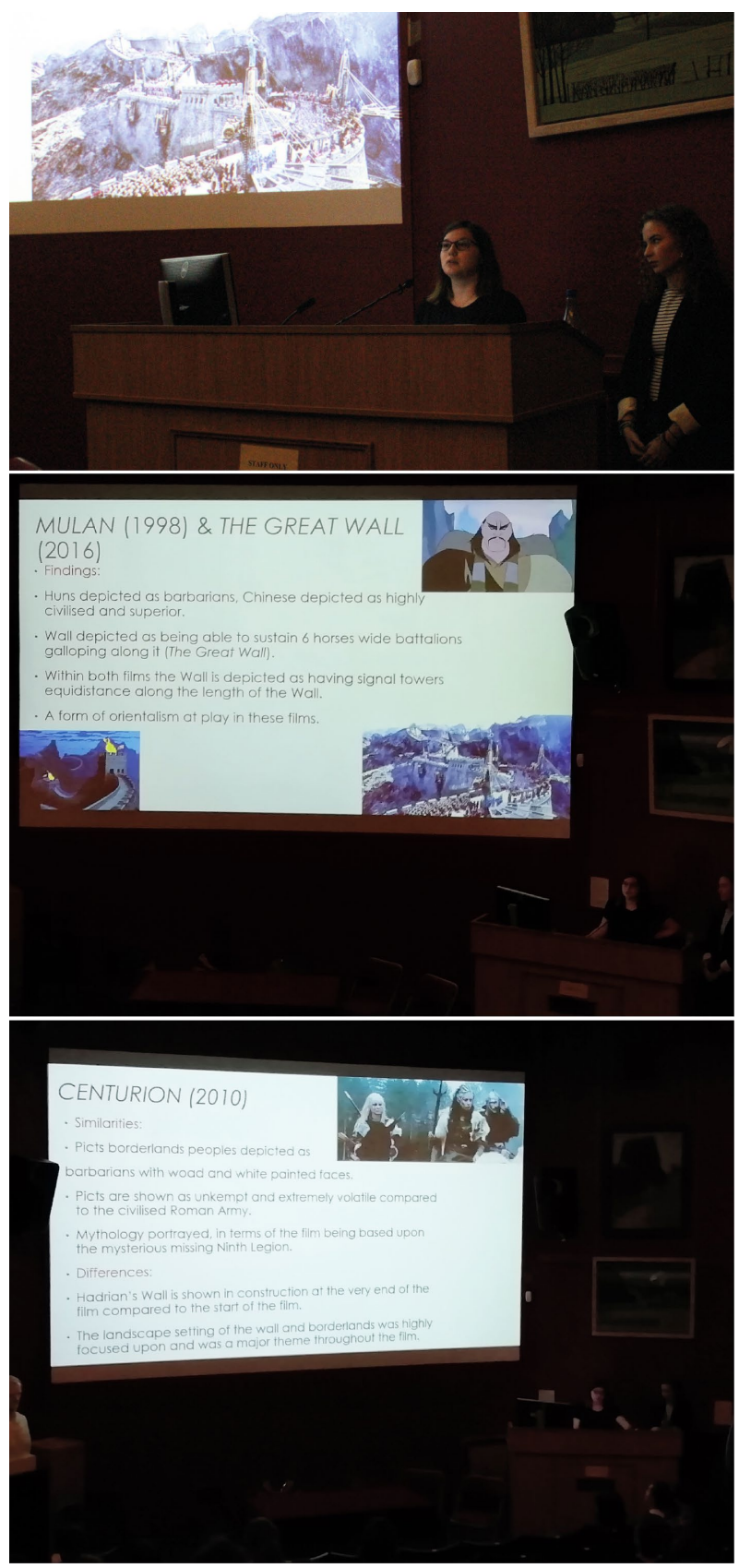

Figure 6: Sophie Billingham and Rebecca Pritchard preseting: 'The Global Perspective: The Public Archaeology of the Great Wall of China' (Photographs: Kieran Gleave and Howard Williams, 2019)

\section{Frontiers in fiction and modernity}

The final section of the conference comprised of three further student presentations. The first, from Rowan Sharp, James Spencer and Emma Vernon, was entitled 'Watching Walls: The Public Archaeology of Fictional Frontiers'. Their talk explored how fictional frontiers may inform public perceptions of archaeological frontiers or borderlands, specifically focusing on the Game of Thronestelevision series (Figure 7). Spencer began the presentation by drawing direct comparisons between The Wall of Westeros and Hadrian's Wall; commenting on how depictions of linear monuments in terms of trade and as cognitive barriers in Game of Thrones can influence public perceptions of frontiers such as Hadrian's wall, both being seen in a similar light. Following this, Vernon discussed how representations of land and family identity in borderland regions within Game of Thrones can influence public perceptions of the archaeology of ancient linear monuments (Vernon this volume). Finally, Sharp presented examples of how filming locations in Northern Ireland, such as the 'Dark Hedges' and Dunluce Castle, have had an impact on visitor numbers, motivation and experience.

The next paper, 'Breaking down the Berlin Wall' by Rebecca Caldwell, Eleanor Boot and Kieran Gleave tackled the challenges to archaeology and heritage professionals posed by such an iconic and controversial monument, especially as it operated during living memory (Figure 8). This was both from the perspective of the residents of Berlin, and visitors to the city, with their differing perspectives. Gleave examined the complexities that interpreting pre-wall 'dark heritage' along the route of the Wall can challenge both national politics and widely accepted public narratives about the archaeology of the Wall, drawing from the Topography of Terror and Invalidenfriedhof cemetery as examples (Gleave this volume). Next, Boot discussed and questioned how the multiple physical manifestations of the Wall during its active years, and narratives from both sides of it should be incorporated into interpretation at sites along the Wall today. She went on to suggest that future interpretations of the Berlin Wall should be altered to convey the message to the public that the wall was adapted continuously throughout its operation. Finally, Caldwell discussed how the Wall should be commemorated and exist in the contemporary 

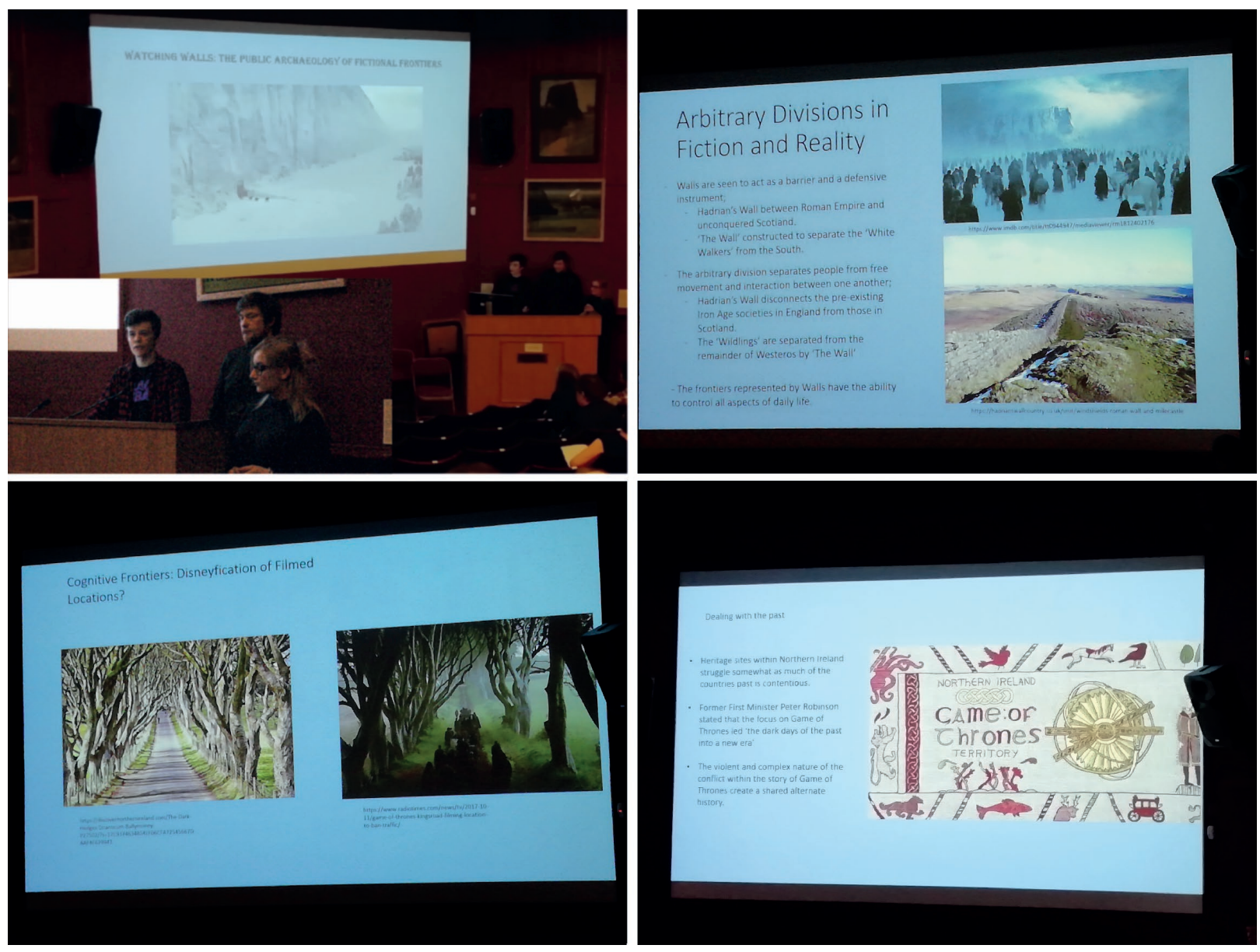

Figure 7: Rowan Sharp, James Spencer and Emma Vernon discussing: 'Watching Walls: The Public Archaeology of Fictional Frontiers' (Photographs: Howard Williams, 2019)

cityscape of Berlin, drawing on Checkpoint Charlie and the East Side Gallery as case studies. The overall conclusion was that the public ought to be able to interact with the wall's materiality and biography for purposes of both memorialisation and learning.

The final presentation from the students brought the debate about borders right up to date, as Maiken Holst gave a paper entitled 'The Political Dimensions of Public Archaeology in Borderlands: Exploring the Contemporary US/Mexican Border' (Figure 9). She examined how archaeology can contribute to political debates regarding this prominent and contested contemporary border (Holst this volume). She emphasised the responsibility of archaeologists to ensure that the past is not misappropriated by politicians and the public in attempting to popularise the notion of a physical border between the countries (see also McAtackney this volume).

\section{The keynote presentations}

The three keynote talks were interspersed with the student presentations and whose contributions provided invaluable insights into the complexities and debates surrounding frontiers and borderlands.

John G. Swogger, an expert archaeological illustrator, spoke about 'Drawing Borders: What Comics can Bring to the Public Archaeology of Frontiers and Borderlands' (see Swogger and Williams this volume). 


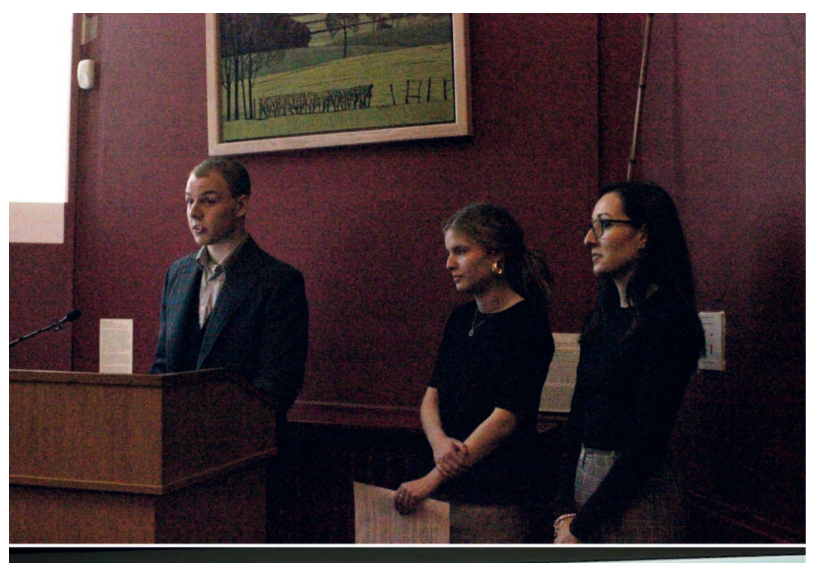

After the Wall

- Once the wall had been broken down in 1989, the ideas that the wall had created did not disappear overnight.

- The effects of the wall can still be seen through the museums in

Berlin and the public

interpretation of those who were there and an 'outsiders' view

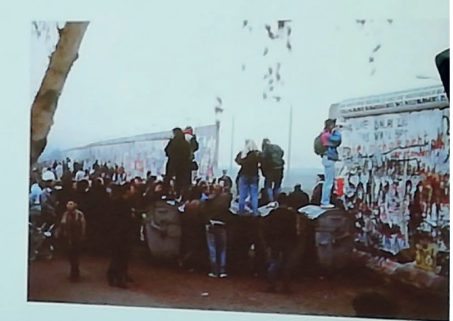

Figure 8: 'Breaking down the Berlin Wall', by Rebecca Caldwell, Eleanor Boot and Kieran Gleave (Photographs: Howard Williams, 2019)

in Public Archaeology'. She drew on her experiences of working with volunteers to overcome preconceived notions of frontiers and borderlands through archaeological practice (Figure 11).

The closing conference keynote - 'The Discomfort of Frontiers: Public Archaeology and the Politics of Offa's Dyke' by Professor Keith Ray (Cardiff University) discussed the contemporary and cultural relevance of Offa's Dyke, especially appropriate as 2019 was also the 50th anniversary of the founding of the Offa's Dyke Association (Figure 12). His talk centred on the fluctuating use of the Dyke as a blunt political symbol and tool, against a much more nuanced picture of its complex physical, cultural and institutional character. He illustrated this argument by presenting and discussing three
He outlined the unique problems in the portrayal and discussion of borders, in that they are often difficult to see, awkward to understand against the mores of today, and often seen as irrelevant in relation to contemporary realities (Figure 10). He proposed archaeologists overcome these significant problems through the use of the comic book medium of graphics with short commentaries to make the borderlands and frontiers more visible, engaging and relevant at all levels. He demonstrated how this particular approach could be used to convey complex ideas about identities and the biographies of frontiers by linking the past and the present, and mobilising community engagement.

Dr Penelope Foreman of Clwyd Powys Archaeological Trust (CPAT) presented 'Crossing the Line: Borders, Barriers and Belonging
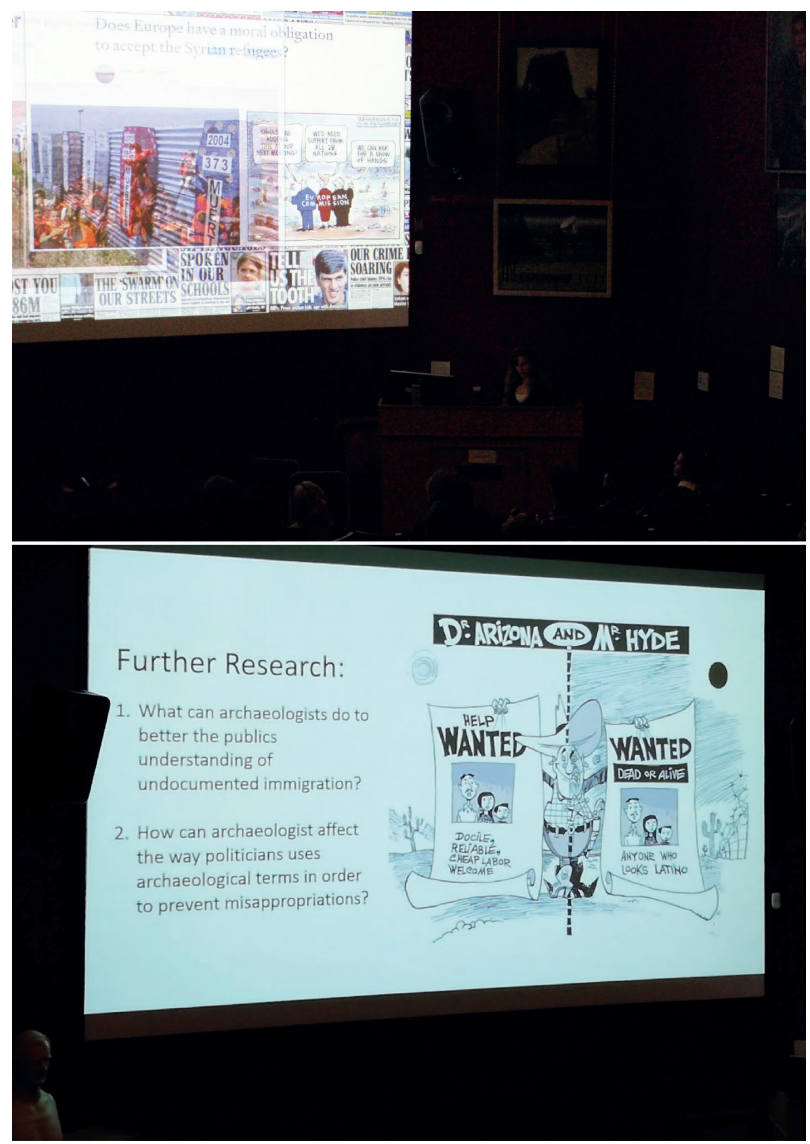

Figure 9: Maiken Holst presenting 'The Political Dimensions of Public Archaeology in Borderlands: Exploring the Contemporary U.S./Mexican Border'. (Photographs: Howard Williams, 2019) 

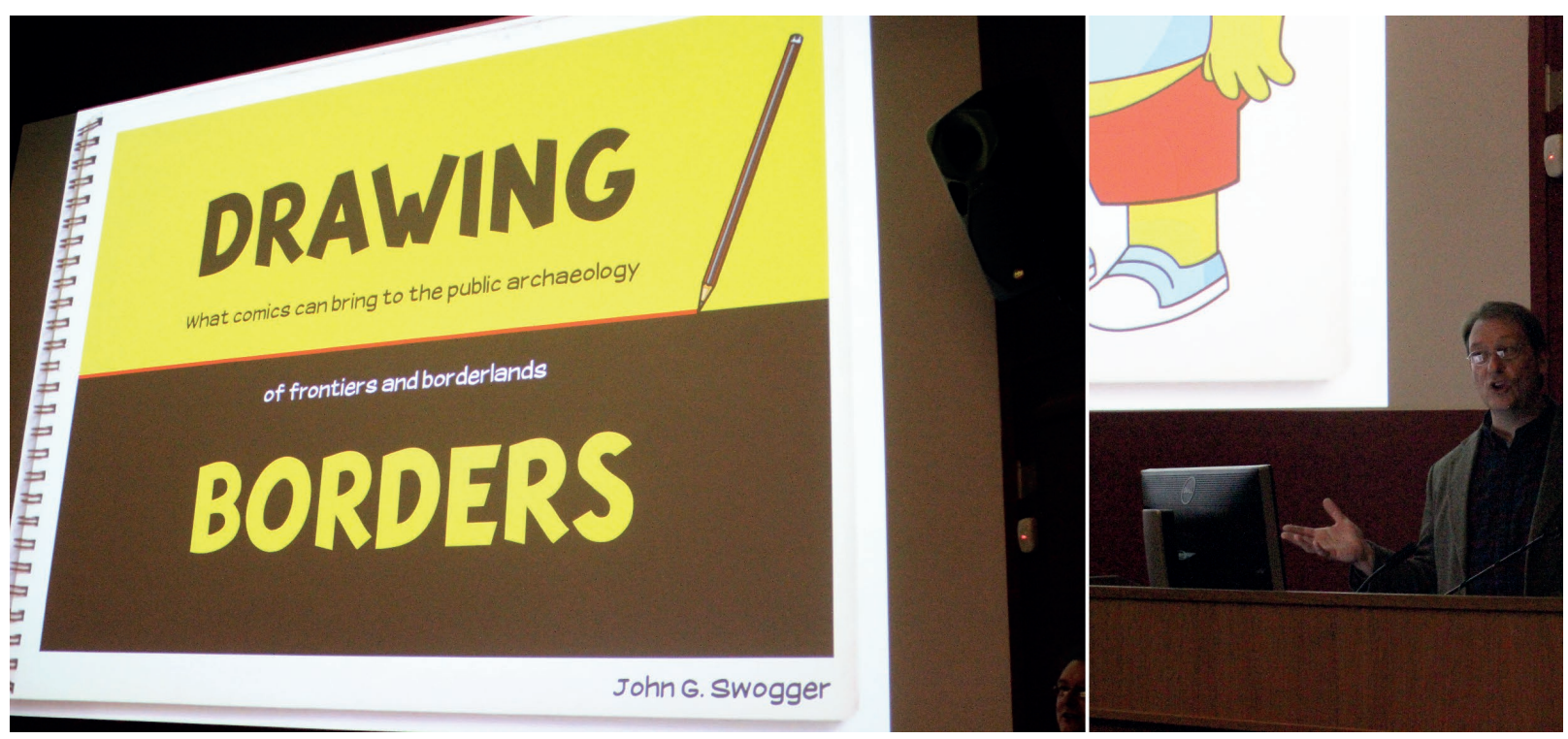

Figure 10 (above): John G. Swogger deliverinng his keynote talk: 'Drawing Borders: What Comics can Bring to the Public Archaeology of Frontiers and Borderlands' (Photographs: Howard Williams, 2019)

Figure 11 (below): Art by John G. Swogger presented as part of the keynote talk by Dr Penelope Foreman: 'Crossing the Line: Borders, Barriers and Belonging in Public Archaeology' (Photograph: Kieran Gleave, 2019)
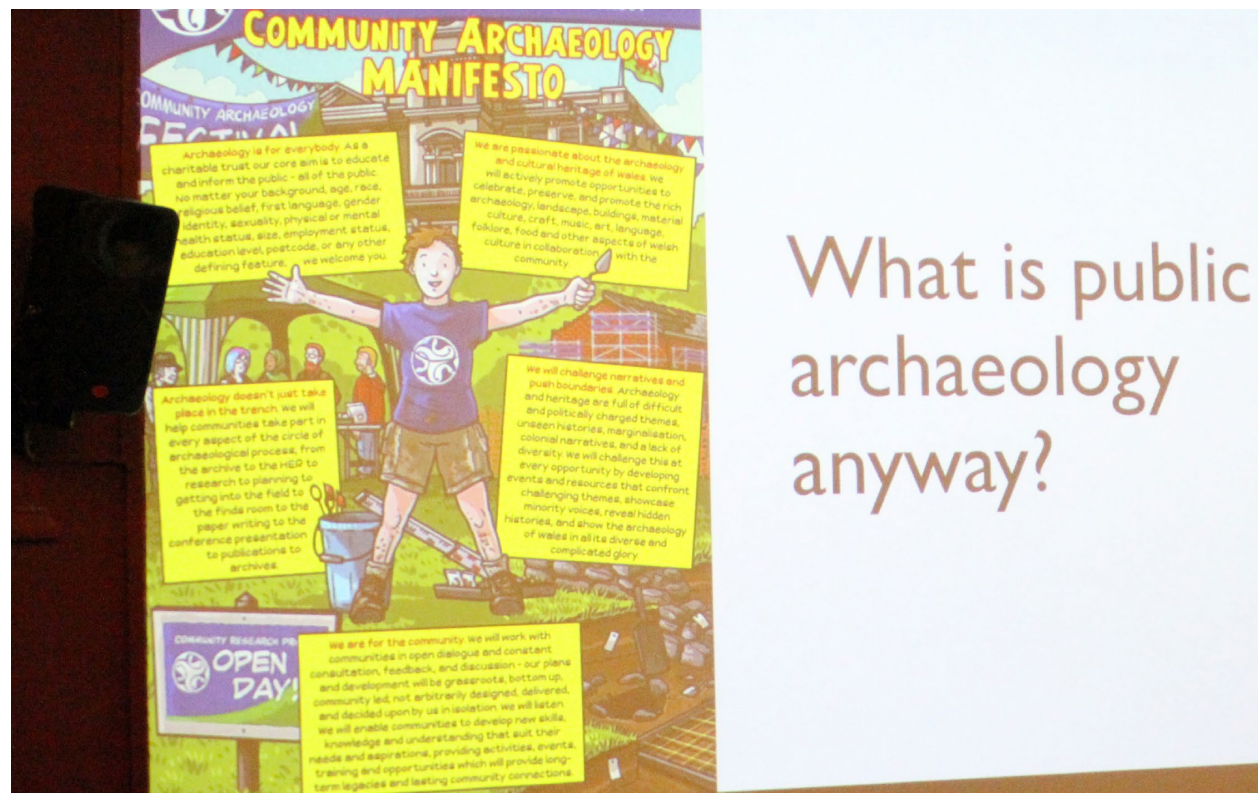
archaeology anyway?

theses - firstly, that any discussion of the Dyke needs to take into account the history of its perception, secondly, that the frontier has always been about more than just the Dyke, and thirdly, that choosing how to present the heritage of this early border has political resonances today. He also reflected on how we might work to better foster borderland community engagement and senses of affinity with Britain's longest monument to ensure its long-term conservation, management and interpretation (Ray and Bapty 2016; Ray this volume). 


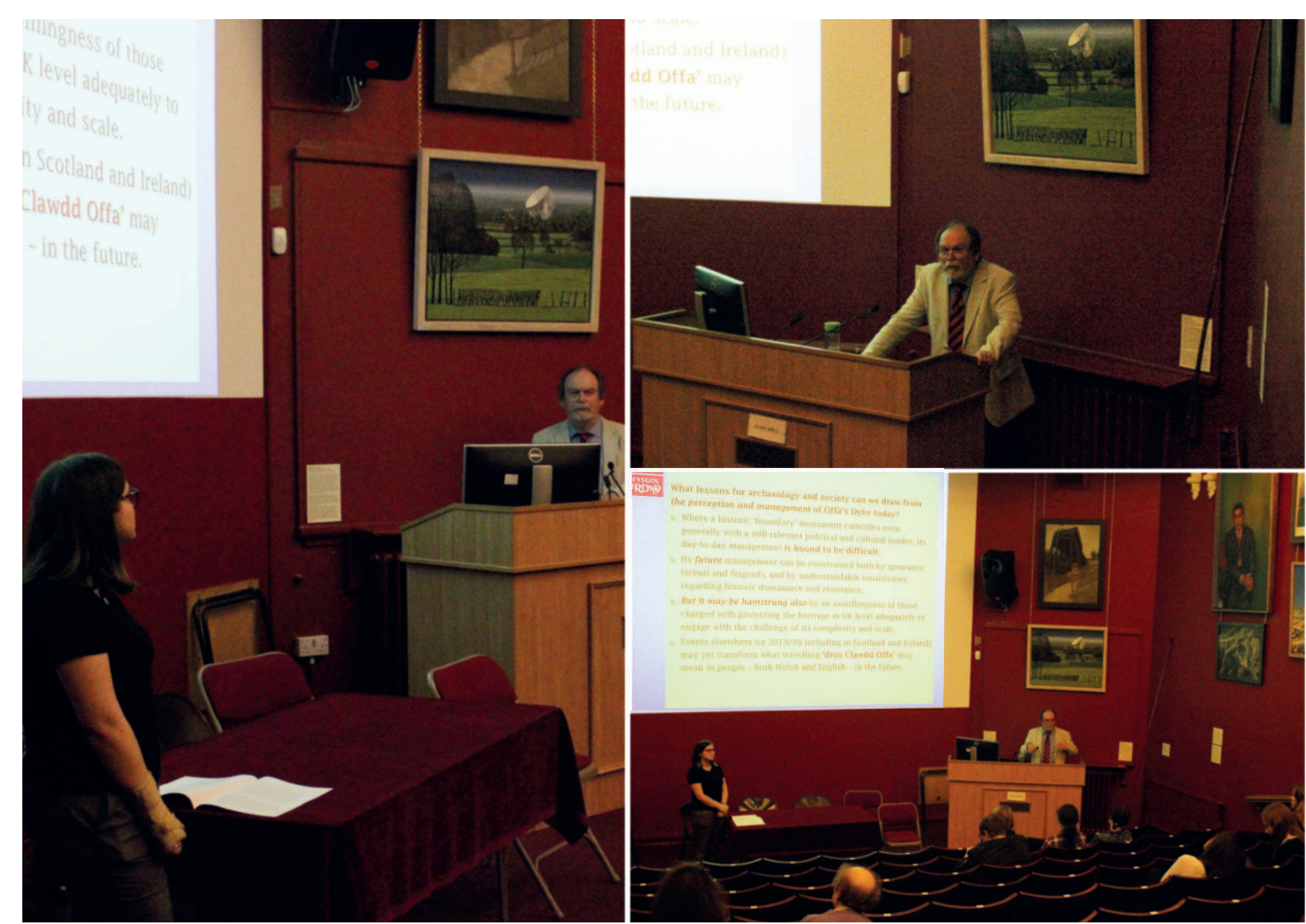

Figure 12 (above): 'The Discomfort of Frontiers: Public Archaeology and the Politics of Offa's Dyke' by Professor Keith Ray, chaired by Sophie Billingham (Photographs: Kieran Gleave and Howard Williams, 2019)

Figure 13 (next page): Artwork devised by John G. Swogger for his conference presentation, featuring a fictional excavation scene inspired by the Pillar of Eliseg (see Williams and Evans 2020). The image prompts us to imagine future strategies for the public archaeology of frontiers and borderlands (John G. Swogger, 2019)

All three guest lecturers provided an insight into the various conceptual and logistical complexities that can arise from engaging the public with different frontiers and borderlands, significantly aiding the students in developing their ideas in preparation for their summative assignments after drawing from their expertise and experience.

\section{From conference to publication}

Of the nineteen students who took part in the conference, four elected to contribute their papers to this volume (Billingham, Gleave, Holst and Vernon). One further student (McMillan-Sloan) had not participated in the conference but proposed a contribution to the book (here, co-authored with Williams). Joining them and responding to an open call for papers, a series of further chapters address key themes (Nevell and Nevell, Brophy, Howell, Swogger and Williams, and two contributions by Williams). These are joined by three academic interviews (Collins, McAtackney, Ray) following a style pioneered in the previous publication arising from the third student conference (Williams and Clarke 2020). 


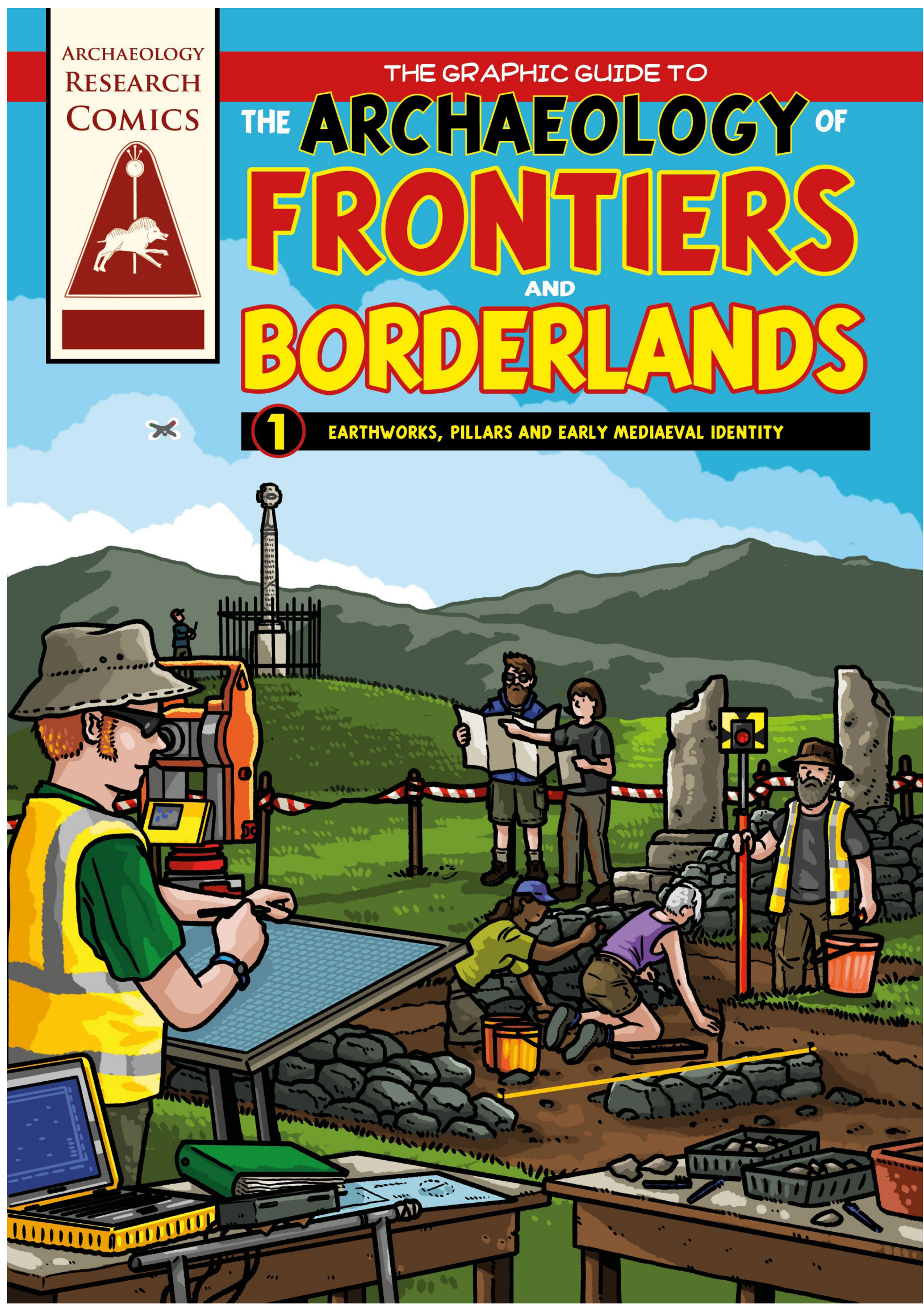


The structure of the book required some reflection, for while a thematic approach was desirable, most chapters tackle multiple themes. The chapter by Nevell and Nevell stands apart as an exploration of public engagement with medieval castles in broad terms, addressing multiple conceptual and physical 'walls' to public engagement as well as how we might challenge insular and nationalistic narratives for the Middle Ages. As their contribution picks out themes subsequently pertinent throughout the collection, it was placed at the start of the book.

Subsequently, the book looks at ancient and recent frontiers and their interactions with heritage. Via interview, Collins has created the first even reflection on the public archaeology of Hadrian's Wall. Next, Brophy considers the Anglo-Scottish border and its pre- and modern- history, along with the impact of the 2014 Scottish Independence Referendum; his specific focus is the Auld Acquaintance Cairn in Gretna. They are joined by the student contributions by Gleave and Holst building on their conference presentations (see above).

The middle of the book draws together five original studies of the Anglo-Welsh borderlands via the consideration of the Cofiwch Dryweryn mural heritage (Howell), the politics and public archaeology of Offa's Dyke (an interview with Ray), the contested landscape of Old Oswestry hillfort (McMillan-Sloan and Williams), and Wat's Dyke's heritage interpretations (Williams) and its envisioning (Swogger and Williams).

Latter part of the book takes us into the treacherous territory of imagined borders and walls, thus illustrating how archaeological perspectives on them have a deep significance beyond the real world in heritage tourism, entertainment and both imagined pasts and fantastical (and horrific) futures. The aforementioned student presentations on Game of Thrones (Vernon) and Hollywood portrays of the Great Wall of China (Billingham) are joined by a consideration of the television series The Walking Dead (Williams). The interview on contemporary wall-building and public archaeology (McAtackney) closes the volume.

\section{Conclusion}

Together, the chapters consider how archaeologists and archaeological research on frontiers and borderlands must navigate complex relationships and political discourses with communities both digital and tangible. We hope this collection encourages further work, contributing to fresh and transformative understandings of how frontiers and borderlands are conserved, managed and interpreted for future generations as well as how they create new senses of identity and community in the present (Figure 13).

At a time of increasing xenophobia and wall-building, critically engaging with how archaeological interpretations and heritage discourses narrate frontiers and borderlands is imperative (see also Hingley 2018). In doing so, we seek not to valorise and celebrate military barriers and socio-political strategies of exclusion past and present, but instead provide critical perspectives on their complex stories and ultimate failures as endeavours. If public archaeologies of frontiers and borderlands worldwide have a single purpose, it is to question our long-term and world-wide propensities to create divisions and to instead celebrate using the strengths of archaeologists' chronological, spatial and material perspectives to investigate frontiers' and borderlands' variances, limitations, fragilities and ultimate redundancies. In this regard, archaeological research and heritage assets harbour rich potential and exhibit powerful lessons for our future. As such, we feel this book contributions new insights in public archaeology and equally it serves as the ideal public archaeology-focused complement to the recent innovative and interdisciplinary edited collection on contemporary borders: Walling In and Walling Out (McAtackney and McGuire 2020). 


\section{Bibliography}

Barclay, G. and K. Brophy. 2020. 'A veritable chauvinism of prehistory': nationalist prehistories and the 'British' late Neolithic mythos. Archaeological Journal, https://www.tandfonline.com/doi/full/10.1080/0 0665983.2020.1769399

Bonacchi, C., M. Altaweek and M. Krzyzanska. 2018. The heritage of Brexit: roles of the past in the construction of political identities through social media. Journal of Social Archaeology 18(2): 174-92.

Breeze, D. 2011. The Frontiers of Imperial Rome. Barnsley: Pen and Sword.

Brophy, K. 2018. The Brexit hypothesis and prehistory. Antiquity 82: 1650-1658.

Gardner, A. 2017. Brexit, boundaries and imperial identities: a comparative view. Journal of Social Archaeology 17(1): 3-26.

Hamilakis, Y. 2018. Introduction: Archaeologies of forced and undocumented migration, in Y. Hamilakis (ed.) The New Nomadic Age. Archaeologies of Forced and Undocumented Migration: 1-19. Sheffield: Equinox.

Hicks, D. and S. Mallet. 2019. Lande: The Calais 'Jungle' and Beyond. Bristol: Bristol University Press.

Hingley, R. 2012. Hadrian's Wall: A Life. Oxford: Oxford University Press.

Hingley, R. 2018. Frontiers and mobilities: the frontiers of the Roman Empire and Europe. European Journal of Archaeology 21(1): 78-95.

Malim, T. 2020. Wat's Dyke and its relationship to Old Oswestry hillfort, in T. Malim and G. Nash (eds) Old Oswestry Hillfort and its Landscape: Ancient Past, Uncertain Future: 145-158. Oxford: Archaeopress.

McAtackney, L and R. McGuire. (eds) 2020. Walling In and Walling Out: Why Are We Building New Barriers to Divide Us? Santa Fe: University of New Mexico Press.

Moshenska, G. 2017. Introduction: public archaeology as practice and scholarship where archaeology meets world, in G. Moshenska (ed.) Key Concepts in Public Archaeology: 1-13. London: UCL.

Naum, M. 2010. Re-emerging frontiers: postcolonial theory and historical archaeology of the borderlands. Journal of Archaeological Method and Theory 17(2): 101-131.

O' Drisceoil, C., M. Leenane, S. Davis, B. Fitzgibbon and M. Teehan. 2014. The Black Pig's Dyke Regional Project 2014. Monaghan: Heritage Council of Ireland.

Polm, M. 2016. Museum representations of Roman Britain and Roman London: a post-colonnial perspective. Britannia 47: 209-241.

Ray, K. and I. Bapty. 2016. Offa's Dyke: Landscape and Hegemony in Eighth-Century Britain. Oxford: Windgather Press.

Stewart, H.E., I. Osterreicher, C. Gokee. and J. De Leon. 2018. Surveilling surveillance: counter-mapping undocumented migration in the USA-Mexico borderlands, in Y. Hamilakis (ed.) The New Nomadic Age. Archaeologies of Forced and Undocumented Migration: 42-57. Sheffield: Equinox.

Williams, H. 2019a. Dead relevant: introducing the public archaeology of death, in H. Williams, B. WillsEve and J. Osborne (eds) The Public Archaeology of Death: 1-16. Sheffield: Equinox.

Williams, H. 2019b. Introduction: public archaeologies as arts of engagement, in H. Williams, C. Pudney and A. Ezzeldin (eds) Public Archaeology: Arts of Engagement: 1-14. Oxford: Archaeopress.

Williams, H. 2020. Living after Offa: Place-Names and Society Memory in the Welsh Marches. Offa's Dyke Journal 2. 
Williams, H. with R. Alexander, R. Bursnell, J. Cave, A. Clarke, A. Ezzeldin, J. Felgate, B. Fisher, B. Humphries, S. Parry, H. Proctor, M. Rajput, C. Richardson and B. Swift. 2019. From Archaeo-Engage to Arts of Engagement, in H. Williams, C. Pudney and A. Ezzeldin (eds) Public Archaeology: Arts of Engagement: 15-35. Oxford: Archaeopress.

Williams, H. and P. Clarke. (eds) 2020. Digging into the Dark Ages: Early Medieval Public Archaeologies, Oxford: Archaeopress.

Williams, H. with P. Clarke, V. Bounds, S. Bratton, A. Dunn, J. Fish, I. Griffiths, M. Hall, J. Keelan, M. Kelly, D. Jackson, S. Matthews, M. Moran, N. Moreton, R. Neeson, V. Nicholls, S. O'Conner, J. Penaluna, P. Rose, A. Salt, A. Studholme and M. Thomas. 2020. Public archaeology for the Dark Ages, in H. Williams and P. Clarke (eds) Digging into the Dark Ages: Early Medieval Public Archaeologies: 1-18. Oxford: Archaeopress.

Williams, H. and L. Delaney. 2019. The Offa's Dyke Collaboratory and the Offa's Dyke Journal. Offa's Dyke Journal 1: 1-31.

Williams, H. and S. Evans. 2020. Death and memory in fragments: Project Eliseg's public archaeology, in H. Williams and P. Clarke (eds) Digging into the Dark Ages: Early Medieval Public Archaeologies: 172-192. Oxford: Archaeopress.

Witcher, R. 2010a. The fabulous tales of the common people, part 1: representing Hadrian's Wall. Public Archaeology 9(3): 126-152.

Witcher, R. 2010b. The fabulous tales of the common people, part 2: encountering Hadrian's Wall. Public Archaeology 9(4): 211-238. 